\title{
ДОСВІД ВИКЛАДАННЯ ДИСЦИПЛІНИ “ФАРМАКОЕКОНОМІКА” ДЛЯ СТУДЕНТІВ СПЕЦІАЛЬНОСТІ “КЛІНІЧНА ФАРМАЦІЯ"
}

О. В. Тригубчак

ДВНЗ “Тернопільський держсавниймедичний університет імені І. Я. Горбачевського МОЗ Украйни”

\author{
EXPERIENCE OF TEACHING THE COURSE \\ "PHARMACOECONOMICS" FOR STUDENTS OF SPECIALTY \\ "CLINICAL PHARMACY"
}

\section{O. V. Tryhubchak}

SHEI "Ternopil State Medical University by I. Ya. Horbachevsky of MPH of Ukraine”

\begin{abstract}
Викладено основні методичні підходи до викладання дисципліни “Фармакоекономіка” студентам фармацевтичного факультету, спеціальності “Клінічна фармація".

Basic methodical approaches of teaching the course "Pharmacoeconomics" are presented for students of Faculty of Pharmacy, specialty "Clinical Pharmacy".
\end{abstract}

Вступ. На етапі реформування системи охорони здоров’я в Україні виникла необхідність професійного підходу до раціонального застосування лікарських засобів. Це знайшло відображення в практичній медицині. Так, згідно з наказом МОЗ України № 531 від 24 липня 2009 року, організація та проведення моніторингу лікувального закладу відбуваються із залученням клінічних провізорів [1].

Запозичений багаторічний закордонний досвід дозволив готувати спеціалістів фармацевтичного профілю за спеціальністю “Клінічна фармація”, що вимагає грунтовного засвоєння клінічних і фармацевтичних дисциплін.

Підготовка фахівців зі спеціальності “Клінічна фармація" у Тернопільському державному медичному університеті ім. І. Я. Горбачевського розпочата в університеті в 2001 році; у 2006 році спеціальність пройшла акредитацію Державної акредитаційної комісії Міністерства освіти і науки України і отримано право на підготовку фахівців освітньо-кваліфікаційного рівня "Спеціаліст”, у 2011 році спеціальність пройшла акредитацію Державної акредитаційної комісії Міністерства освіти і науки України, а з 2007 року функціонує магістратура даного профілю.

Підготовку спеціалістів зі спеціальності “Клінічна фармація" здійснюють 18 кафедр медичного факультету та 5 випускаючих кафедр фармацевтичного факультету: фармакогнозії з медичною ботанікою, фармацевтичної хімії, технології ліків, клінічної фармації, управління та економіки фармації.
Основна частина. Однією з профільних дисциплін, що оволодівають студенти спеціальності “Клінічна фармація", є фармакоекономіка [2, 3], яка згідно з типовою робочою програмою [4] за кредитно-модульною системою викладається у VIII та IX семестрах навчання. На предмет виділено 206 годин / 5 кредитів.

У весняному семестрі 4 курсу навчання студенти вивчають модуль 1 "Загальна фармакоекономіка" (180 годин), що включає змістові модулі 1 "Теоретичні основи фармакоекономіки" і 2 "Методологія фармакоекономічного аналізу”. Для освоєння матеріалу передбачено 20 годин лекцій, 80 годин практичних занять та 80 годин СПРС. У кінці семестру передбачено підсумковий тестовий контроль.

Студентам 5 курсу виділено 126 годин для оволодіння знань та вмінь 3 модуля 2 "Прикладна фармакоекономіка”, що розділений на змістові модулі 3 “Фармакоекономіка як економічна складова формулярної системи та системи стандартизації медичної допомоги” 44 “Фармакоекономічний аналізтерапії найбільш поширених захворювань”. Для цього виділено 12 годин лекцій, 72 години семінарських занять та 42 години СПРС. В кінці семестру знання студентів контролюються на іспиті.

Додатково з фармакоекономіки вимагається написання курсової роботи та проходження виробничої практики.

Студенти спеціальності “Клінічна фармація” після закінчення навчання складають державний випускний іспит, частиною якого $€$ фармакоекономіка. 
Всі лекції читаються з мультимедійним супроводом. Перед лекцією лектор розміщує на свій e-mail інформацію для студентів - тексти лекції з відеоінформацією. Ознайомившись з інформацією, студенти приходять на лекцію підготовленими. Це підвищує рівень засвоєння студентами лекційного матеріалу.

Викладачі постійно працюють над вдосконаленням необхідного навчально-методичного забезпечення дисципліни. Переглядаються і оновлюються зміст й ілюстративний матеріал лекцій з урахуванням сучасних тенденцій розвитку світової фармації.

Особливістю навчання в Тернопільському державному медичному університеті є методика “єдиного дня”, згідно з якою робочий тиждень для студентів становить 5 днів, з них один день - лекційний, чотири дні - практичні заняття. На практичних заняттях студент протягом усього робочого дня (6 академічних годин) працює за схемою: практична робота 3 год, семінарське обговорення - 2 год, письмовий контроль - 1 год.

На практичних заняттях використовуються методичні рекомендації до аудиторної роботи з дисципліни за кожним з розділів програми, ситуаційні задачі. В ході роботи студенти використовують прайс-листи діючої навчальної аптеки ТОВ “Ера-Тер”, що знаходиться на території кафедри. Це дозволяє навчитися проводити оптимізацію фармакотерапії в реальних умовах. Семінарська частина проходить у формі дискусії, вирішення практичних ситуацій, студенти $є$ активними і крім обов' язкового матеріалу цікавляться актуальними питаннями.

3 метою полегшення засвоєння матеріалів тем виготовлено навчальні таблиці. Функціонування при кафедрі бібліотеки, де зібрана сучасна література та доступ до мережі Інтранет сприяє доступу до літератури з розділу фармакоекономічного аналізу для підготовки студентів до занять й іспитів.

Для полегшення орієнтування студентів в індивідуальній навчальній програмі web-портал університету в розділі “'Інтранет / студентські орієнтири /на допомогу студентам” наповнений робочими програмами, розкладом лекцій та практичних занять, презентаціями лекцій, матеріалами підготовки студентів до лекцій та практичних занять, а також методичними вказівками. Всі матеріали розміщені у форматі $\mathrm{html}$, що дозволяє студентам обробляти запропоновані матеріали на персональних комп'ютерах.

Новвовведенням слід відмітити також дублювання цієї інформації в системі Moodle.2,0 в сучасному форматі pdf. Звичайно презентації лекцій залишаються 3 розширенням ppt. За матеріалами до практичних за- нять для кожної теми створено базу даних тестів, що дозволяє студентам самостійно в домашніх умовах перевірити освоєння матеріалу напередодні перед заняттям. На контрольній частині практичного заняття студент може покращити свою оцінку шляхом написання 24 тестових завдань 35 варіантами відповіді, одна 3 яких є однозначно правильною.

У кінці семестру студенти складають семестровий тестовий іспит. Для підготовки до цього, крім традиційних консультацій, на сайті університету оприлюднено збірник тестових завдань для підготовки до семестрового тестового іспиту, що вміщує 1626 тестових завдань 1318 тестових питань до 135 рисунків, що розміщені у “'Збірнику рисунків для підготовки до семестрового тестового іспиту”. В день складання іспиту знання 3 дисципліни контролюються за допомогою комісії незалежного оцінювання із залученням сканування та комп'ютерного контролю. Ефективність такої роботи підтверджується збігом результатів поточної успішності впродовж навчального року та оцінкою за складання семестрового іспиту.

Важливе позитивне значення також має виконання курсової роботи, опанування практичних навичок протягом навчання та проходження студентами 2тижневої виробничої практики з фармакоекономіки на базі лікувально-профілактичних закладів.

3 метою розвитку творчих навичок та науково-дослідної роботи заохочується підготовка студентами рефератів, курсових робіт, обов'язковим елементом яких є власні дослідження. Студенти беруть активну участь у роботі наукового гуртка, публікують тези і статті, виступають $з$ доповідями на наукових конференціях й конгресах. Протягом останніх років було захищено 7 дипломних робіт, що присвячені фармакоекономічним дослідженням лікарських засобів для лікування соціально значимих захворювань.

У процесі підготовки до проведення державних іспитів був розроблений план заходів, що включав складання білетів, організацію консультацій і чергування викладачів на кафедрі. Враховуючи мінливість нормативних документів, які стосуються лікарського забезпечення населення медикаментами, були проведені тематичні консультації з переліку нових нормативних актів. Для забезпечення студентів інформацією стосовно нормативних актів викладачами кафедри сформовано електронний варіант необхідних для вивчення наказів. У січні 2013 року видавництвом "Укрмедкнига" видано збірник нормативних актів 3 організації роботи аптечних підприємств “Фармацевтичне законодавство”, де висвітлено сучасні вимоги до лікарських засобів, по- 
рядок проведення доклінічних та клінічних досліджень, моніторингу безпеки та ефективності лікарських засобів та інші аспекти фармацевтичної галузі [5].

Для проведення державного іспиту з фармакоекономіки було складено і затверджено методичною комісією екзаменаційні білети, які включали 3 теоретичні запитання з розділів "Характеристика фармакоекономічних категорій”, “Методи фармакоекономічного аналізу” та “Фармакоекономічна оцінка схем лікування захворювань” і 1 ситуаційну задачу для вибору раціональної фармакотерапії, використовуючи фармакоекономічні дослідження методом “Мінімізація вартості", "Витрати - ефективність”, “Витрати - користь”, “Загальна вартість захворювання” або шляхом побудови “Дерева рішень”.

Державний іспит проходить в комплексі з фармакогнозією, фармацевтичною опікою з клінічною фармакологією. Державний іспит з фармакоекономіки складали 5 студентів, що навчались за спеціальністю “Клінічна фармація".

Теоретичну частину іспиту студентам було зараховано при обговоренні трьох питань. Аналіз практичної частини іспиту показав, що студенти добре оволоділи методами фармакоекономічних досліджень, знають номенклатуру лікарських засобів, нормативні документи та можуть застосовувати свої знання на практиці при вирішенні ситуаційних завдань.

Результати проведення держіспиту показали, що більшість студентів сумлінно підготувалась до нього і спостерігається підвищення зацікавленості до

\section{Література}

1. Порядок проведення моніторингу безпеки та ефективності лікарських засобів у стаціонарах закладів охорони здоров’я: наказ МОЗ України № 531 від 24 липня 2009 р.

2. Заліська О. М. Фармакоекономіка : підручник / О. М. Заліська; за ред. Б. Л. Парновського. - Львів : Афіша, 2007. $-374 \mathrm{c}$.

3. Яковлєва Л. В. Фармакоекономіка : навчальний посібник для студентів вищих навчальних закладів / Л. В. Яковлєва. - Вінниця : Нова книга, 2009. - 208 с.
}

фармакоекономіки. Якісна успішність змінювалася від 72,73\% (2006 р.), 74,20 \% (2007 р.), 78,26\% (2008 р.), 85,70 \% (2009 р.) та коливається в діапазоні 80-90\% впродовж останніх років.

Наші випускники працюють у системі охорони здоров'я, зокрема клінічними провізорами, провізорами аптек чи медичними представниками. Свої знання i вміння колишні студенти в подальшому поглиблюють та досягають успіхів. Так, В. П. Пида та А. С. Вольська виконали кандидатські дисертації і працюють асистентами кафедри фармакології з клінічною фармакологією. Ю. А. Равлів після закінчення магістратури працює асистентом кафедри управління та економіки фармації і виконує кандидатську дисертацію. Н. Окаринська є викладачем у Тернопільському медичному коледжі. Асистент кафедри управління та економіки фармації Г. М. Коріневська прирівняла диплом до магістра у Чеській Республіці. Серед наших випускників Т. Сивак вступила до аспірантури в США, О. Клак підтвердила диплом у Великобританії, I. Вонс працює за спеціальністю в Канаді.

Висновок. Використання досвіду викладання фармакоекономіки в Тернопільському державному медичному університеті дозволяє проаналізувати сильні та слабкі сторони з метою покращення подачі навчального матеріалу, а також виділити основні методичні положення для застосування на практиці при викладанні фармакоекономіки провізорам спеціальностей “Фармація” i “Технологія парфумерно-косметичних засобів".

4. Фармакоекономіка. Типова програма навчальної дисципліни для студентів вищих фармацевтичних навчальних закладів та фармацевтичних факультетів вищих медичних навчальних закладів III-IV рівнів акредитації. Спеціальність: 7.110206 “Клінічна фармація”. - Київ, 2012.

5. Фармацевтичне законодавство (Нормативні акти 3 організації роботи аптечних підприємств) / під ред. д-ра фарм. наук, проф. Т. А. Грошового. - Тернопіль : Укрмедкнига, 2013. -569 c. 